УДК 37

DOI $10.21661 / \mathrm{r}-472882$

\title{
Г.А. Соколова
}

\section{РОЛЬ ИГРОВОГО ЭЛЕМЕНТА В ВВОДНО-ФОНЕТИЧЕСКОМ КУРСЕ ПРИ ИЗУЧЕНИИ ИНОСТРАННЫХ ЯЗЫКОВ}

Аннотация: в данной статье рассматриваются некоторые аспекты преподавания иностранного языка на начальных этапах, подчеркивается важность использования игрового элемента при работе над вводнофонетическим курсом.

Ключевые слова: игра, звук, вводно-фонетический курс, произночение, иностранный язык, родной язык, гимнастика речевого аппарата, скороговорки.

\section{G.A. Sokolova}

\section{THE ROLE OF THE GAME ELEMENT IN THE INTRODUCTORY-PHONETIC COURSE IN THE STUDY OF FOREIGN LANGUAGES}

Abstract: this article discusses some aspects of teaching a foreign language at initial stages, the importance of using the game element when working on the introductory-phonetic course is emphasized.

Keywords: game, sound, introductory-phonetic course, pronunciation, foreign language, native language, gymnastics of the speech apparatus, tongue twisters.

В современном мире изучение иностранных языков приобретает все большую популярность. Человечество становится более коммуникативным, преодолевая географические границы, постигает новые культуры и нуждается в знании нескольких иностранных языков.

С помощью компьютерных и коммуникативных технологий созданы уникальные возможности для изучения иностранных языков как самостоятельно, так и в учебной группе. На сегодняшний день разработаны многочисленные компьютерные программы для овладения иностранными 
языками, они позволяют тренировать навыки письма, чтения, аудирования.

Однако данные разработки требуют огромной усидчивости со стороны обучающихся, желающих быстро приобрести навыки и освоить иностранный язык, и лишены личного общения с наставником-преподавателем и другими учениками. Такие программы богаты игровыми элементами лишь на начальном уровне изучения иностранного языка и предназначены в основном для детской и подростковой аудитории. Разработки для взрослых групп обучающихся требуют много времени для их освоения.

Занятия по иностранным языкам на начальном уровне, на которых осуществляется работа над вводно-фонетическим курсом, контролируемая преподавателем, в студенческих группах и группах для взрослых обладают некоторыми преимуществами. На таких уроках создается атмосфера живого общения, преподаватель тонко чувствует психологический настрой своей аудитории и варьирует подачу и отработку учебного материала в зависимости от ситуации во время учебного процесса. Введение игрового элемента на занятиях по иностранным языкам снимает сложность в освоении и тренировке произношения новых звуков пока еще незнакомого иностранного языка, служит средством мотивации обучающихся, у которых появляется желание говорить правильно и красиво на иностранном языке и обладать таким же совершенным произношением, как у профессионала-педагога, и дает им возможность «переключиться» с родного языка или другого иностранного языка на изучаемый язык [2, с. 3].

Игровые элементы могут включать в себя разнообразные виды упражнений, длительность каждого из которых варьируется от 3 до 5 минут. Так, короткая гимнастика речевого аппарата, заставляющая обучающихся улыбнуться или состроить гримасу, создает позитивный настрой в учебной группе, что отражается в быстром запоминании правильного артикуляционного уклада речевых органов, характерного для изучаемого иностранного языка [2, с. 3].

Работа над дикцией, четкостью произношения особенно важна при изучении иностранных языков. Необходимо знать правильный способ 
образования каждого звука, т. к. отклонение в установке органов речевого аппарата при произнесении того или иного звука ведет к искажению реализации этого звука, а это в свою очередь - к искажению слова, к изменению его смысла [1, с. 12].

Большим успехом пользуются скороговорки в группах разных возрастов. Они способствуют созданию положительного эмоционального настроения, вызывают у обучающихся интерес к живому звучащему слову. Хорошо подобранные, с выразительностью рассказанные преподавателем скороговорки помогают установить контакт с аудиторией и вызвать положительные эмоции, что позитивно отражается на развитии и совершенствовании речи учащихся [4, с. 4].

Каждая скороговорка уже несет в себе определенный характер, настроение, окраску и даже темп. Так, хорошо известная английская скороговорка:

She sells sea shells on the seashore.

The shells that she sells are seashells, I'm sure.

вызывает в представлении обучающихся достаточно спокойную, теплую и даже солнечную с преобладанием песочных тонов картинку. По мнению исследователей, сам звук /о̀/ похож на звук сыплющегося песка или шум морского прибоя. В связи со спокойным характером скороговорки и преобладанием в ней долгих гласных звуков темп проговаривания этой скороговорки не может быть очень быстрым [3, с. 12-13].

Такая известная немецкая скороговорка:

Brauchbare Bierbrauerbauer brauen brausendes Braunbier.

Brausendes Braunbier brauen brauchbare Bierbrauerbauer.

создает динамичный эффект непрерывного процесса, в данном случае пивоварения, и побуждает обучающихся реализовать эту скороговорку в достаточно быстром темпе.

Скороговорка как речевое явление имеет место почти во всех языках и является эффективным упражнением при изучении иностранной речи. Скороговорка так же, как и стихотворение или песня, способна помочь 
изучающему иностранный язык прочувствовать каждый новый для него звук и отработать правильное произношение [3, с. 15-16].

Методика работы над скороговорками достаточно проста: начиная с медленного и отчетливого проговаривания каждого слова и каждого звука, дойти до максимально четкого и быстрого произнесения всей скороговорки. При заучивании скороговорок усилению мыслительных процессов помогает моторика рук. Для достижения большего эффекта полезно использовать скороговорки в таких играх, как «Кто быстрее?» (игроки соревнуются в быстроте и правильности произнесения скороговорки), «Паровозик» (каждый участник игры получает по одному слову из скороговорки, затем последовательно реализуется вся фраза), «Эхо» (участники игры по очереди произносят за ведущим отдельно каждое слово скороговорки, при этом каждый следующий участник должен повторить слово тише, чем предыдущий), «Конкурс» (задача участников игры - придумать скороговорку на заданный ведущим звук с определенным количеством слов), «Поле чудес» (на доске из выбранной скороговорки выписываются только служебные части речи, вместо знаменательных частей речи ставятся пропуски, участникам игры необходимо восстановить зашифрованную скороговорку), «Выключи звук!» (ведущий медленно одними движениями губ имитирует произнесение одной из изученных скороговорок, задача остальных участников-угадать скороговорку и произнести ее быстро и без ошибок), «Скороговорка-трансформер» (в этой игре подбираются скороговорки с парными звуками «глухой - звонкий», задача участников - произнести скороговорку, заменяя глухой звук звонким и наоборот) [3, с. 18-21].

Эффективность такой работы велика, поскольку игровая форма помогает изучающим иностранный язык не только принять и полюбить такое замечательное речевое упражнение как скороговорка, но и научиться правильному и четкому произнесению звуков и слов неродного языка. Знание скороговорок изучаемого иностранного языка расширяет представление учащихся об этом языке, его истории, культуре и традициях [3, с. 21-22]. 
Другим видом речевого упражнения являются краткие тексты, представляющие собой аутентичные шутки, анекдоты или юмористические зарисовки. Они могут быть предложены обучающимся как тексты для прочтения, когда формируется навык чтения, или как слуховые диктанты, когда формируется навык аудирования в конце первых уроков вводно-фонетического курса и обучающихся приучают к пониманию и записи иностранной речи на слух [2, с. 4].

Аутентичные тексты, носящие страноведческий характер и призванные стать «ключом» к постижению реалий иноязычного культурного пространства, a также ориентированные на понимание более сложных оригинальных материалов, обеспечивают обучающихся информационной насыщенностью и развивают у них способность учитывать нормы и традиции разных культур, что ведет к формированию у студентов коммуникативной компетенции [2, с. 4].

Использование на занятиях по иностранным языкам мини-викторин по прочтению или проговариванию скороговорок на скорость и четкость произношения, а также по прочтению кратких аутентичных текстов на скорость создает игровой настрой у обучающихся, конкурентный дух таких языковых состязаний оказывает положительное влияние на речевую работу учащихся [2, с. 4].

Введение мнемотехник по отработке отдельных звуков или звуковых комбинаций с использованием лексических единиц также может привнести игровую нотку в ход занятия по иностранному языку, где обучающиеся тренируют и совершенствуют кратковременную память [2, с. 4].

Работа над правильным произношением достаточно трудна и требует большей сконцентрированности внимания обучающихся. Использование игрового элемента на занятиях вводно-фонетического курса облегчает эту работу, делает изучение иностранных языков увлекательным и интересным, тренирует память обучающихся и создает у них положительную мотивацию, что позитивно влияет на процесс освоения иностранного языка. 


\section{Список литературы}

1. Вербовая Н.П. Искусство речи / Н.П. Вербовая, О.М. Головина, В.В. Урнова. - М.: Искусство, 1977. - 303 с.

2. Долгих В.Г. Deutsch. Wir fangen an! Начальный курс немецкого языка: Учебное пособие. - М.: ТЕЗАУРУС, 2013. - 159 с.

3. Лаптева Е.В. 1000 английских и 1000 русских скороговорок: Учебное пособие. - М.: Астрель: АСТ, 2007. - 447 с.

4. Тарабарина Т.А. Пословицы, поговорки, потешки скороговорки: популярное пособие для родителей и педагогов / Т.А. Тарабарина, Н.В. Елкина. - Ярославль: Академия развития, 2011. - 224 с.

\section{References}

1. Verbovaia, N.P., Golovina, O.M., \& Urnova, V.V. (1977). Iskusstvo rechi., 303. M.: Iskusstvo.

2. Dolgikh, V.G. (2013). Deutsch. Wir fangen an! Nachal'nyi kurs nemetskogo iazyka: Uchebnoe posobie., 159. M.: TEZAURUS.

3. Lapteva, E.V. (2007). 1000 angliiskikh i 1000 russkikh skorogovorok: Uchebnoe posobie., 447. M.: Astrel'; M.: AST.

4. Tarabarina, T.A., \& Elkina, N.V. (2011). Poslovitsy, pogovorki, poteshki skorogovorki: populiarnoe posobie dlia roditelei i pedagogov., 224. Iaroslavl': Akademiia razvitiia.

Соколова Галина Александровна - канд. филол. наук, доцент ФГБОУ ВО «Московский государственный лингвистический университет», Россия, Москва.

Sokolova Galina Aleksandrovna - candidate of philosophical sciences, associate professor at the Moscow State Linguistic University, Russia, Moscow. 